\title{
HUBUNGAN STATUS GIZI DAN KADAR HEMOGLOBIN DENGAN PRESTASI BELAJAR SISWA SMA NEGERI 14 PALEMBANG
}

\author{
Manuntun Rotua \\ Jurusan Gizi Poltekkes Palembang \\ Email:manuntun_rotua@yahoo.com
}

Diterima : 6 Desember 2018 Direvisi : 12 Desember 2018 Disetujui : 17 Desember 2018

\begin{abstract}
Abstrak
Prestasi belajar merupakan titik awal keberhasilan siswa di masa depan dan merupakan pertimbangan kemampuan bersaing siswa untuk melanjutkan sekolah, status gizi dapat berpengaruh terhadap kondisi fisik dan kemampuan siswa dalam mengikuti proses belajar, faktor yang dapat mempengaruhi prestasi belajar, antara lain faktor biologis, psikologis dan keadaan lingkungan siswa (Syafitri 2009).

Tujuan penelitian ini untuk mengetahui hubungan status gizi, dan kadar hemoglobin dengan prestasi belajar siswa .

Jenis penelitian analitik dengan rancangan penelitian cross sectional. Populasi siswa kelas X dan XI, berjumlah 621 siswa. Sampel berjumlah 67 siswa. Data prestasi belajar ditentukan berdasarkan nilai rata-rata dengan mata pelajaran standar nasional, data asupan energi protein diperoleh melalui wawancara recall $3 \times 24$ jam, data status gizi diperoleh dengan metode antropometri BMI/U CDC dan kadar hemoglobin diperoleh melalui pemeriksaan metode Cyanmet hemoglobin. Analisis yang digunakan adalah uji Chi-square.

Hasil penelitian menunjukan status gizi normal sebanyak 38 siswa $(56,7 \%)$, Kadar hemoglobin normal sebanyak 38 siswa ( 56.7\%), dan Prestasi belajar yang baik sebanyak 38 siswa (56.7\%). Setelah di lakukan uji Chi-square maka tidak ada hubungan yang bermakna antara status gizi dengan prestasi belajar siswa SMA Negeri 14 Palembang ( $p$ value $=0.379$ ) $0.05)$. Ada hubungan antara kadar hemoglobin dengan prestasi belajar siswa SMA Negeri 14 Palembang $(p$ value $=0.046>0.05)$.
\end{abstract}

\section{Kata kunci: Status Gizi, Kadar Hemoglobin, Prestasi Belajar}

\section{PENDAHULUAN}

Kurangnya asupan gizi pada anak usia sekolah mengakibatkan anak menjadi cepat lelah, kondisi lemah, dan cenderung sakit, sehingga anak sekolah seringkali absen serta mengalami kesulitan untuk mengikuti dan memahami pelajaran.
Sehingga banyak murid yang mengulang kelas atau meninggalkan sekolah sebagai akibat kurang asupan gizi merupakan masalah yang serius bagi upaya mencerdaskan kehidupan bangsa melalui pendidikan (Nurdiani, 2011). Kekurangan energi akibat pembakaran unsur karbohidrat, protein dan lemak dapat 
mengakibatkan tubuh menjadi lesu, kurang bergairah untuk melakukan berbagai kegiatan seperti proses belajar (Kartasapoetra dan Marsetyo, 2003).

Kadar hemoglobin ( $\mathrm{Hb})$ dapat mempengaruhi prestasi belajar. Anak yang anemia berpotensi mengalami kesulitan dalam berkonsentrasi, daya ingat rendah, serta kapasitas pemecahan masalah rendah, tingkat kecerdasan lebih rendah dan terjadi gangguan perilaku (Maharani (2008) dalam Styawan, 2012).

Faktor-faktor yang mempengaruhi terjadinya anemia diantaranya adalah asupan mikronutrien seperti; zat besi, seng, tembaga, folat, vitamin B-6, vitamin-B. Seseorang yang mengalami anemia dapat memiliki tingkat kesegaran jasmani yang kurang (Cendani, 2010). Defisiensi zat besi berdampak pada fungsi otak, terutama terhadap fungsi sistem neurotransmitter (pengantar saraf) yang mengakibatkan daya konsentrasi, daya ingat, kemampuan belajar terganggu, ambang batas rasa sakit meningkat, fungsi kelenjar tiroid dan kemampuan mengatur suhu tubuh menurun (Almatsier, 2009).

Akibat anemia pada anak dapat menyebabkan penurunan daya tahan tubuh terhadap penyakit, gangguan pada pertumbuhan sel tubuh juga sel otak, penurunan fungsi kognitif, rendahnya kemampuan fisik, gangguan motorik dan koordinasi, pengaruh psikologis dan prilaku, penurunan prestasi belajar, dan rendahnya kemampuan intelektualitas yang dapat menyebabkan dampak secara luas yaitu menurunnya kualitas sumber daya manusia (Manampiring, 2008).
Menurut Almatsier

(2009) kurangnya asupan gizi merupakan penyebab langsung dari status gizi rendah, sedangkan penyebab tidak langsung yang dominan meliputi tingkat ekonomi yang kurang, pendidikan umum dan pendidikan gizi yang kurang. Akibat dari status gizi kurang adalah perkembangan otak yang tidak sempurna yang menyebabkan kognitif dan kemampuan belajar terganggu. (Soekirman dalam Isdaryanti, 2007). Jika permasalahan kurang gizi tidak segera diatasi, maka akan berdampak pada kematian anak, penurunan kemampuan belajar, kemampuan kognitif, anggaran pencegahan dan perawatan yang meningkat dan penurunan produktivitas kerja (Ulfani, 2011).

Dalam Isdaryanti (2007), hubungan antara status gizi dan kadar hemoglobin dengan prestasi belajar murid sekolah dasar di daerah endemis malaria Kabupaten Nabiri, setelah diuji dengan Chi Square pada taraf $\alpha=5 \%$ menyatakan bahwa ada hubungan antara status gizi, kadar hemoglobin dengan prestasi belajar (Huwae, 2005). Status gizi dan prestasi belajar serta status hemoglobin anak SD di daerah IDT perkotaan yang dilakukan oleh Pranadji dan Ratnaningsih memberikan hasil adanya perbedaan nyata pada prestasi belajar setelah diuji menggunakan uji $T$-tes pada taraf $\alpha=5 \%$.

$\begin{array}{ccr}\text { Dalam } & \text { tingkat nasional, } \\ \text { masyarakat di } & \text { Indonesia } & \text { yang }\end{array}$ mengkonsumsi energi di bawah kebutuhan minimal sebesar $40,7 \%$, dan protein $37 \%$, sedangkan tingkat provinsi Sumatera Selatan yang mengkonsumsi energi di bawah kebutuhan minimal sebesar 45,4\% dan protein sebesar 42,4\% (RISKESDAS, 2010). Berdasarkan data tersebut, sangat 
diperlukan perhatian terhadap asupan gizi energi dan protein anak remaja untuk provinsi Sumatera Selatan.

Di Sumatera Selatan status gizi remaja menurut $\mathrm{TB} / \mathrm{U}$ untuk status gizi buruk sebesar 9,3\% gizi kurang sebesar $23,6 \%$ dan gizi baik sebesar $67,1 \%$ (RISKESDAS, 2010). Berdasarkan data tersebut menunjukkan bahwa status gizi remaja di Sumatera Selatan untuk status gizi buruk relatif cukup tinggi sebesar 1,9 $\%$ lebih tinggi jika dibandingkan dengan persentase tingkat nasional yaitu sebesar $7,2 \%$. Status gizi buruk akan mengakibatkan kelainan pada jaringan otak seseorang yang berpengaruh terhadap kemampuan belajar, rangsangan dari lingkungan sangat rendah, terjadinya perubahan kepribadian anak (Moehji, 2003).

Keadaan gizi dan kesehatan remaja menjadi permasalahan yang serius terutama mengenai keberadaan status zat besi di dalam darah yaitu salah satu penyebab penyakit anemia. Anemia merupakan salah satu masalah gizi mikro yang cukup serius dengan prevalensi tertinggi dialami oleh Indonesia. Hasil Riskesdas 2013 tercatat bahwa prevalensi anemia yang terjadi di indonesia adalah $21,7 \%$ dengan proporsi $20,6 \%$ di perkotaan dan $22,8 \%$ di pedesaan

SMA Negeri 14 Palembang merupakan salah satu SMA Negeri yang ada di Kenten Laut Palembang. Sekolah ini jarang dijadikan tempat untuk dilakukan penelitian terutama dibidang kesehatan. Setelah dilakukan survey pendahuluan diketahui bahwa SMA Negeri 14 Palembang merupakan SMA berprestasi yang unggul dalam kegiatan ektrakulikuler dan organisasi sehingga siswa-siswi di sekolah ini selalu dipadatkan oleh aktifitas di sekolah. Namun sayangnya sekolah ini masih belum mendapatkan perhatian dari pihak Puskesmas diwilayah itu, terbukti dengan jarang dilakukannya penyuluhan kesehatan pada siswa-siswi SMA tersebut, data awal didapatkan hemoglobin siswa SMA dari 58 siswa terdapat Anemia 46,6\%, tidak anemia $(53,4 \%)$.

\section{METODOLOGI PENELITIAN}

Jenis Penelitian ini merupakan penelitian Analitik dengan menggunakan rancangan penelitian Cross Sectional dimana variabel terikat dan variabel bebas diukur sekali dan pada saat yang bersamaan (Sastroasmoro, 1995). Tempat pelaksanaan penelitian ini di SMA Negeri 14 Palembang, subjek penelitian adalah siswa-siswi SMA Negeri 14 Palembang kelas $\mathrm{X}$ dan $\mathrm{XI}$ yang terpilih secara random. Besar subjek penelitian sebanyak 63 siswa yang masuk criteria inklusi. Setelah data terkumpul dilakukan editing, koding, dan entry dalam file computer kemudian dianalisis secara statistic dengan menggunakan SPSS 21. Data kemudian dianalisis menggunakan uji uji ChiSquare. Nilai signifikan dalam penelitian ini adalah $\mathrm{p}<0.05$ 
HASIL DAN PEMBAHASAN

A. HASIL

1. Analisis Univariat.

Tabel 1. Karakteristik Siswa Berdasarkan Umur (n=67)

\begin{tabular}{clcc}
\hline No & \multicolumn{1}{c}{ Karakter Siswa } & Frekwensi (n) & Prensetasi )\%) \\
\hline $\mathbf{1}$ & Umur & 7 & \\
& 14 tahun & 27 & 10,4 \\
& 15 tahun & 30 & 40,3 \\
& 16 tahun & 3 & 44,8 \\
& 17 tahun & $\mathbf{6 7}$ & 4,5 \\
& Total & & $\mathbf{1 0 0}$ \\
\hline
\end{tabular}

Berdasarkan tabel 1 , menunjukkan umur siswa dalam penelitian ini $\geq 16$ tahun sebanyak 30 orang (44.8\%).

Tabel 2. Distribusi Frekwensi Responden Menurut Status Gizi.

\begin{tabular}{ccc}
\hline Status Gizi & Frekwensi (n) & Presentasi $(\boldsymbol{\%})$ \\
\hline Kurung & 16 & 23,9 \\
Normal & 38 & 56,7 \\
Overweight & 5 & 7,5 \\
Obesitas & 8 & 11,9 \\
Total & $\mathbf{6 7}$ & $\mathbf{1 0 0 , 0}$ \\
\hline
\end{tabular}

Berdasarkan tabel 2 menunjukkan jumlah sampel berjumlah 67 siswa diketahui tingkat status gizi kurang sebanyak 16 (23.9\%) siswa, status gizi normal sebanyak 38 (56.7\%) siswa, Kegemukan sebanyak 5 (7,5\%) siswa dan Obesitas sebanyak 8 siswa $(11,9 \%)$ siswa.

Tabel 3. Distribusi Frekwensi Responden Menurut Kadar Hemoglobin

\begin{tabular}{ccc}
\hline $\begin{array}{c}\text { Kadar } \\
\text { Hemoglobin }\end{array}$ & Frekwensi (n) & Presentasi $(\boldsymbol{\%})$ \\
\hline Kurang & 29 & 43,3 \\
Normal & 38 & 56,7 \\
Total & $\mathbf{6 7}$ & $\mathbf{1 0 0 , 0}$ \\
\hline
\end{tabular}

Berdasarkan tabel 3 menunjukkan tingkat kadar hemoglobin siswa berkategori kurang sebanyak 29 siswa (43.3\%), berkategori normal sebanyak 38 siswa (56.7\%). 
Tabel 4. Distribusi Frekwensi Responden Menurut Tingkat Prestasi

\begin{tabular}{|c|c|c|c|}
\hline Interval & Tingkat Prestasi & Frekwensi (n) & Presentasi (\%) \\
\hline$>65$ & Baik & 38 & 56,7 \\
\hline$\leq 65$ & Tidak baik & 29 & 43,3 \\
\hline \multicolumn{2}{|c|}{ Total } & 67 & 100,0 \\
\hline
\end{tabular}

Berdasarkan tabel 4 menunjukkan nilai prestasi yang baik sebanyak 38 (56.7\%) siswa, prestasi yang kurang sebanyak 29 (43.3\%) siswa.

\section{Analisis Bivariat}

Tabel 5. Distribusi Frekwensi Prestasi Belajar Menurut Tingkat Status Gizi

\begin{tabular}{|c|c|c|c|c|c|c|c|}
\hline \multirow{3}{*}{ Status Gizi } & \multicolumn{4}{|c|}{ Prestasi } & & & \multirow{3}{*}{ P. Value } \\
\hline & \multicolumn{2}{|c|}{ Tidak baik } & \multicolumn{2}{|c|}{ Baik } & \multicolumn{2}{|c|}{ Total } & \\
\hline & n & $\%$ & $\mathbf{n}$ & $\%$ & $\mathbf{n}$ & $\%$ & \\
\hline Kurus & 9 & 56,3 & 7 & 43,8 & 16 & 100 & \\
\hline Normal & 13 & 34,2 & 25 & 65,8 & 38 & 100 & ( 370 \\
\hline Gemuk & 3 & 60 & 2 & 40 & 5 & 100 & $0,3 / 9$ \\
\hline Obesitas & 4 & 50 & 4 & 50 & 8 & 100 & \\
\hline Total & 29 & 43,3 & 38 & 56,7 & 67 & 100 & \\
\hline
\end{tabular}

Berdasarkan tabel 5, menunjukkan bahwa responden dengan nilai prestasi baik memiliki status gizi kurang sebanyak 7 (43.8\%), status gizi normal sebanyak 25 $(65,8 \%)$ siswa, dibandingan dengan status gizi kurus sebanyak $7(43,8 \%)$ siswa, status gizi gemuk sebanyak $2(40 \%)$ siswa dan obesitas sebanyak 4 (50\%) siswa.

Hasil penelitian uji statistic Chisquare menyimpulkan bahwa antara status gizi berdasarkan $\left(\mathrm{BB} / \mathrm{TB}^{2} \mathrm{M}\right)$ dengan prestasi belajar, tidak ada pengaruh yang signifikan antara status gizi terhadap prestasi belajar dengan diperoleh nilai $\mathrm{p}$ value > $0.05(0,379)$. Terlihat pada tabel 5 diatas.

Penelitian ini sesuai dengan penelitian Ismail (2010) yang menyatakan tidak ada pengaruh yang signifikan antara status gizi terhadap prestasi belajar siswa.

Hasil penelitian ini tidak sesuai dengan hasil penelitian yang dilakukan oleh Krisnawati dkk (2009) bahwa ada hubungan antara status gizi dengan prestasi belajar siswa. Hal ini disebabkan terdapat perbedaan dalam penelitian ini dengan penelitian yang dilakukan oleh Krisnawati yaitu dalam hal instrumen yang digunakan untuk pengambilan data, dimana peneliti dalam penelitian ini menggunakan indeks antropometri IMT/U untuk menentukan status gizi sedangkan pada penelitian yang dilakukan oleh Krisnawati menggunakan KMS (kartu menuju sehat) 
Tabel 6. Distribusi Frekwensi Prestasi Belajar Menurut Tingkat Kadar Hemoglobin

\begin{tabular}{|c|c|c|c|c|c|c|c|}
\hline \multirow{3}{*}{$\begin{array}{c}\text { Kadar } \\
\text { Hemoglobin }\end{array}$} & \multicolumn{4}{|c|}{ Prestasi } & \multirow{2}{*}{\multicolumn{2}{|c|}{ Total }} & \multirow{3}{*}{ P. Value } \\
\hline & \multicolumn{2}{|c|}{ Tidak baik } & \multicolumn{2}{|c|}{ Baik } & & & \\
\hline & $\mathbf{n}$ & $\%$ & n & $\%$ & $\mathbf{n}$ & $\%$ & \\
\hline Rendah & 17 & 58,6 & 12 & 41,4 & 29 & 100 & \\
\hline Normal & 12 & 31,6 & 26 & 68,4 & 38 & 100 & 0,046 \\
\hline Total & 29 & 43,3 & 38 & 56,7 & 67 & 100 & \\
\hline
\end{tabular}

Berdasarkan Tabel 6, menunjukkan bahwa responden dengan kadar hemoglobin normal memiliki prestasi belajar baik sebanyak $26(68,4 \%)$ siswa, dibandingan dengan kadar Hemoglobin rendah dan prestai belajar baik sebanyak $12(41,4 \%)$ siswa.

Hasil penelitian uji statistic Chisquare diperoleh nilai $\mathrm{p}$ value $<0.05$ $(\mathrm{p}=0,046)$, sehingga dapat disimpulkan bahwa terdapat adanya hubungan antara Kadar Hemoglobin dengan prestasi belajar. Terlihat pada tabel 6 diatas.

Penelitian ini sesuai dengan hasil penelitian Nordin (2011) yang menyatakan bahwa ada hubungan antara kadar hemoglobin dengan prestasi akademik siswa siswi Kabupaten Deli Serdang.

Menurut Santoso 2010, kadar hemoglobin dapat mempengaruhi prestasi belajar, anak yang anemia dapat berpotensi mengalami kesulitan dalam berkonsentrasi, daya ingat rendah.

Faktor-faktor yang dapat menyebabkan derajat prestasi berubah dalam Syafitri (2009) dan dalam Hakim (2001) yaitu dibagi menjadi dua bagian, faktor internal yaitu dalam diri siswa dan faktor eksternal dari luar siswa, dengan penjelasan salah satunya memiliki kondisi kesehatan fisik, kondisi yang sehat dan segar.

\section{PEMBAHASAN}

Seorang siswa yang bersikap conserving(apatis) terhadap ilmu pengetahuan biasanya cenderung mengambil pendekatan belajar yang sederhana dan tidak mendalam. Sebaliknya, seorang siswa yang berintelegensi tinggi dan mendapat dorongan positif dari orang tuanya, mungkin akan memilih pendekatan belajar yang lebih mementingkan kualitas hasil pembelajaran (Syah, 2010).

Soemantri dalam Isdaryanti (2007) menyatakan bahwa kekurangan gizi akan menyebabkan pertumbuhan dapat terganggu, jumlah sel dalam otak berkurang dan terjadi ketidakmatangan dan ketidaksempurnaan organisasi biokimia dalam otak, hal itu berpengaruh terhadap perkembangan kecerdasan anak.

Hal ini menyatakan bahwa status gizi berdasarkan indeks IMT $\left(\mathrm{BB} / \mathrm{TB}^{2}\right)$ bukan satu-satunya faktor yang mempengaruhi prestasi belajar siswa, karna masih banyak factor lain yang tidak diteliti dalam penelitian ini seperti, lingkungan, aspek psikologis dan aspek belajar. 
Menurut Arisman (2010) kartu menuju sehat berfungsi sebagai alat bantu pemantauan gerak pertumbuhan, bukan penilaian status gizi. Peneliti menduga bahwa faktor lingkungan yang paling berpengaruh terhadap prestasi belajar siswa, terutama lingkungan keluarga siswa itu sendiri. Dimana dari hasil penelitian yang dilakukan bahwa pekerjaan orang tua sebagian besar adalah pedagang kecil $(49,2 \%)$ yang berjualan di pasar tentu mengakibatkan terbatas waktu anak bersama-sama dengan orang tuanya. Ditambah lagi latar belakang pendidikan orang tua yang masih rendah, apabila orang tua juga tidak menyadari pentingnya pendidikan bagi anak maka akan mengurangi motivasi dan dukungan bagi siswa itu sendiri dalam proses belajar.

Menurut Zulaiha (2006), Keadaan status gizi dan indeks prestasi merupakan gambaran apa yang dikonsumsi anak sekolah dalam jangka waktu yang lama dapat berupa gizi kurang maupun gizi berlebih. Zat-zat gizi seperti; karbohidrat, protein, maupun zat gizi lainnya khususnya zat besi, dalam metabolism tubuh berperan dalam proses berpikir atau atau proses penalaran serta daya konsentrasi dan sangat berkaitan erat dengan efisiensi belajar. Dengan keadaan gizi yang baik diharapkan berdampak pada prestasi belajar yang baik pula.

\section{KESIMPULAN DAN SARAN}

\section{Kesimpulan}

Hasil penelitian uji statistic Chi-square menyimpulkan Bahwa antara status gizi berdasarkan $\left(\mathrm{BB} / \mathrm{TB}^{2} \mathrm{~m}\right)$ dengan prestasi belajar diperoleh nilai $\mathrm{p}$ value $<0.05$ $(\mathrm{p}=0,046)$, terdapat adanya hubungan antara Kadar Hemoglobin dengan prestasi belajar. diperoleh nilai $\mathrm{p}$ value $<0.05$ $(\mathrm{p}=0,046)$,

Saran

1. Menjadikan Pendidikan Kesehatan sebagai pengetahuan tentang termasuk gizi pada anak agar selalu mengkonsumsi makanan yang sehat dan bergizi seimbang dalam mata pelajaran di SMA Negeri 14 Palembang.

2. Perlu diadakan kerjasama orang tua murid dan pihak sekolah untuk terus mengontrol dan memberikan motivasi belajar pada anak dan menjadikan prestasi belajar anak sebagai tanggung jawab bersama.

\section{DAFTAR PUSTAKA}

Almatsier, S. 2009. Prinsip Dasar Ilmu Gizi. Jakarta: PT Gramedia Pustaka Utama.

Cendani, C. 2010. Hubungan Asupan Mikronutrien terhadap Kadar Hemoglobin dengan Kesegaran Jasmani Remaja Putri. Artikel Penelitian. Universitas Diponegoro.

Isdaryanti, C. 2007. Asupan Energi Protein, Status Gizi, danPrestasi Belajar Anak Sekolah Dasar Arjowinangun I Pacitan. Skripsi. Universitas Gadjah Mada.

Ismail, T.B. 2010 Pengaruh Status Gizi dengan Tingkat Prestasi Akademik Anak-anak Sekolah Dasar di Kota Medan. Skripsi. Universitas Sumatera Utara.

Kartasapoetra, G dan Marsetyo. 2003. Ilmu Gizi Korelasi Gizi, 
Kesehatan, dan Produktivitas Kerja. Jakarta: PT Rineka Cipta.

Kemenkes RI. 2010.Riset Kesehatan Dasar Riskesdas 2010. Jakarta: Kemenkes

Kemenkes RI. 2005. Angka Kecukupan Gizi Rata-rata yang Dianjurkan Bagi Bangsa Indonesia. Keputusan Menteri Kesehatan RI Nomor:

1593/MENKES/SK/XI/2005. Jakarta: Kemenkes

Maharani, E. F. 2012. Tingkat Kecerdasan, Asupan Energi dan Protein, dan Aktivitas Fisik Terhadap Prestasi Belajar Siswa SMA Negeri 6 Bogor. Skripsi. Institut Pertanian Bogor. http://repository.ipb.ac.id/handle/ 123456789/60802yang diakses pada tanggal 25 Juli 2013.

Manampiring, A. E. 2008. Prevalensi Anemia dan Tingkat Kecukupan Zat Besi pada Anak Sekolah Dasar di Desa Minaesa Kecamatan Wori Kabupaten Minahasa Utara. Karya Ilmiah. Universitas Sam Ratulangi.
Nordin, N. B. 2011. Hubungan Kadar Hemoglobin dengan Prestasi Akademik Siswa-siswi SD Negeri No.101837 Suka Makmur Kecamatan Sibolangit Kabupaten Deli Serdang Tahun 2011. Karya Tulis Ilmiah. Universitas Sumatera Utara.

Styawan, D. R.2012. Hubungan Pola Makan dengan Kejadian Anemia pada Anak Usia Sekolah Dasar 612 tahun di SD Negeri 1 Rowosari Kecamatan

Supariasa, I. D. N, dkk. 2002. Penilaian Status Gizi. Jakarta: Penerbit Buku Kedokteran EGC.

Syafitri, R. 2009. Hubungan Motivasi Belajar Terhadap PrestasiBelajar Siswa Di Smp Muhammadiyah 1 Medan. Tugas Akhir. Universitas Sumatera Utara.

Zulaiha, Widajanti. Hubungan kecukupan asam eikosapentanoat (EPA), asam dokosaheksanoat (DHA) ikan dan status gizi dengan prestasi belajar siswa (tesis) Universitas Diponegoro; 2006 